\title{
KEAMANAN PADA E-COMMERCE USAHA KECIL DAN MENENGAH
}

\author{
Zen Munawar,ST,S.Kom.,M.Kom \\ Dosen Prodi Manajemen Informatika \\ Politeknik LP3I Bandung \\ E-mail: munawarzen@gmail.com
}

\begin{abstract}
Abstrak : E-commerce untuk usaha kecil dan menengah menjadi target yang sangat baik untuk pelaku serangan jahat. Pada usaha kecil dan menengah tidak memiliki sumber daya yang diperlukan untuk menangani serangan secara efektif. Pada organisasi besar dan sebagian organisasi menengah memiliki tim yang berdedikasi untuk menangani insiden keamanan dan mencegah serangan di kemudian hari. Sedangkan kebanyakan usaha kecil dan menengah tidak memiliki kemampuan untuk menangani insiden seperti yang dilakukan pada organisasi besar. Keamanan situs e-commerce sangat penting untuk kepatuhan terhadap hukum dan peraturan serta mendapatkan dan mempertahankan kepercayaan konsumen, mitra dan stack holder. Standar keamanan telah ditetapkan oleh berbagai organisasi untuk membantu memandu keamanan pada server usaha kecil dan menengah, namun, banyak dari standar tersebut atau pedoman terlalu mempunyai nilai yang sangat mahal. Penelitian ini ini akan memaparkan bagaimana serangan dilakukan dan bagaimana usaha kecil dan menengah dapat secara efektif dapat mengamankan jaringan dengan biaya ekonomis.
\end{abstract}

Kata Kunci : keamanan e-commerce, keamanan usaha kecil menengah, keamanan server, informasi keamanan

\section{Pendahuluan}

Selama dua dekade terakhir, usaha/bisnis di hampir setiap sektor ekonomi dunia telah mendapat manfaat dari teknologi perdagangan elektronik. Namun, minat dalam $e$ commerce relatif baru. Secara komersial, e-commerce dapat disebut sebagai kegiatan yang berusaha menciptakan transaksi yang panjang antara perusahaan dan individu, juga melibatkan dalam pertukaran uang, barang atau tugas. E-commerce mengacu pada penerapan TIK untuk proses dalam perusahaan, dan mungkin untuk transaksi dengan pelanggan dan pemasok (Fletcher, 2004). Penggunaan Aktivitas internet dan e-bisnis telah membangkitkan minat yang besar di Indonesia. Pemerintah telah menyesuaikan kebijakan ekonomi mereka untuk meningkatkan pembangunan ekonomi dengan mendukung promosi e-bisnis.

Kebanyakan usaha kecil dan menengah (UKM) telah menyadari bahwa, untuk bersaing dalam pemasaran usahanya, sebagai kuncinya adalah mengadaptasi proses bisnis menjadi bagian dari Internet. E-commerce telah menjadi transformasi besar bagi kebanyakan usaha kecil dan menengah. Internet telah mengubah perdagangan tradisional menjadi $e$ commerce, dan telah terbukti menjadi platform yang sukses untuk bisnis usaha kecil dan menengah. Implementasi kegiatan e-bisnis di UKM menimbulkan banyak masalah. Cara baru melakukan bisnis ini membutuhkan staf dengan keahlian dalam teknologi baru dan 
UKM belum tentu memiliki staf TI yang berdedikasi untuk memungkinkan mereka mendapatkan keunggulan kompetitif yang diperlukan (Lawson et. al, 2003).

Usaha kecil dan menengah adalah target yang mudah bagi penyerang karena mereka biasanya memiliki dana terbatas dan tidak memiliki personel yang berdedikasi untuk memantau, memperbarui dan mempertahankan sistem e-commerce yang mereka miliki.

\section{Tinjauan Pustaka}

Merencanakan penerapan e-commerce, menyesuaikan e-niaga dalam bisnis harus menjadi bagian integral dari strategi keseluruhan perusahaan termasuk juga dengan ukm. Perencanaan sangat penting untuk mengeksploitasi peluang dan potensial manfaat. Untuk usaha menengah lebih mengembangkan atau setidaknya mengembangkan rencana $e$ commerce dari usaha kecil. Manfaat yang diharapkan dari e-commerce. Beberapa manfaat yang dari e-commerce adalah operasi yang lebih efisien, pengurangan biaya, meningkatkan jumlah pelanggan, pemasaran yang lebih efisien dan peluang bisnis baru.

Popularitas e-commerce adalah banyaknya manfaat operasional yang dirasakan dapat membawa ke praktik dalam pembelian (Wagner et. Al, 2002). Contoh dari manfaat ini adalah penghematan biaya yang dihasilkan dari transmisi pembelian yang cepat informasi terkait pesanan; dan meningkatkan peluang untuk kemitraan pemasok-pembeli melalui pendirian jaringan komunikasi bisnis-ke-bisnis. (Dell, 1999). E-niaga dapat meningkatkan efisiensi rantai suplai dengan menyediakan informasi waktu nyata terkait ketersediaan produk, tingkat persediaan, status pengiriman, dan persyaratan produksi (Radstaak dan Ketelaar, 1998).

Selain itu, secara efektif dapat menghubungkan informasi permintaan pelanggan ke fungsi rantai pasokan hulu dan kemudian memfasilitasi operasi rantai pasok (demanddriven) (Kalakota dan Whinston, 1997). Meskipun manfaat potensial tersebut, sebagian besar perusahaan tidak tertarik untuk merangkul e-commerce sebagai alat pembelian (Pawar dan Driva, 2000). Beberapa rintangan utama untuk keberhasilan penerapan eniaga termasuk sejumlah masalah keamanan, hukum dan keuangan, tidak sedikit dari itu kasus bisnis yang tidak memenuhi syarat untuk pengenalannya (Taylor, 1999).

Pada tahun 1994, muncul layanan pihak ketiga pertama untuk memproses penjualan kartu kredit online mulai muncul "(Roos, n.d.). Dengan kemampuan untuk menerima kartu kredit secara online, usaha tidak lagi menjadi tradisional. Saat inilah e-commerce dimulai. Hal ini menjadi tantangan untuk mendapatkan kepercayaan, menjaga kepercayaan dan membangun hubungan dengan mitra, pelanggan, klien, dan pemasok. Hubungan dan kepercayaan yang bisa menghabiskan waktu lama untuk dapat diperoleh dengan cepat dihancurkan dengan pelanggaran dalam keamanan.

\subsection{Tantangan E-commerce}

Serangan keamanan siber secara eksplisit ditujukan untuk usaha kecil semakin meningkat dari tahun ke tahun (Rahman \& Lackey, 2013), dengan masing-masing pelanggaran diperkirakan biayanya \$ 263.000 (Symantec, 2016). Tantangan dengan e-commerce telah terjadi untuk berhasil mengintegrasikan keamanan yang efektif ukuran dan mekanisme 
untuk melindungi bisnis dari dikompromikan oleh penyerang. Keamanan yang efektif itu penting untuk kelangsungan bisnis, kepercayaan dari klien, dan kepatuhan dengan industri tertentu terhadap undang- undang. Satu saja pelanggaran keamanan dapat membebani bisnis dan menghabiskan banyak uang, bahkan mematikannya.

Keamanan bukan hanya jenis "set and forget" masalah. Keamanan yang efektif melibatkan analisis menyeluruh, implementasi, memperbarui dan memantau. Konstan keterlibatan dengan keamanan bisa menjadi sesuatu yang jera bagi sebagian orang. Beberapa orang tidak mau mengambil tugas menangani dengan keamanan. Ini adalah tugas utama, dan memang demikian juga tugas yang sangat penting.

\subsection{Masalah Etis dengan E-commerce}

Perusahaan yang menggunakan internet untuk berbisnis harus mematuhi standar etika yang sama secara online mereka offline. Jika mereka tidak mengikuti standar etika yang sama, mereka menghadapi hal yang sama konsekuensi. Reputasi yang rusak dan hilangnya kepercayaan jangka panjang dapat terjadi karena tidak mengikuti standar etika. Melindungi informasi konsumen harus menjadi perhatian utama untuk bisnis. Biaya bisa terlihat tinggi dan manfaatnya tampak rendah, itulah sebabnya mengapa beberapa bisnis tidak merasa perlu untuk benar mengamankan situs web e-commerce mereka. Ketika melakukan pembelian online, konsumen harus memiliki rasa keamanan umum. Meskipun tidak ada cara untuk sepenuhnya mengamankan informasi konsumen, bisnis harus mengambil tindakan pencegahan sebanyak mungkin, sementara masih memungkinkan untuk dapat digunakan. Teknologi telah merevolusi cara masyarakat beroperasi dan melakukan bisnis.

Teknologi tiap saat terus berubah, penjahat terus mencari metode serangan baru, dan itu adalah tanggung jawab pengguna dan administrator berbagai teknologi untuk menggunakannya dengan cara yang etis dan mematuhi semua hukum dan peraturan. Bisnis perlu memastikan infrastruktur e-commerce mereka selalu diperbarui dengan pembaruan terkini dan kebutuhan keamanan.

\subsection{Ancaman terhadap Bisnis}

Bisnis yang terkena risiko berkaitan dengan e-commerce:

Kerugian Finansial Langsung: · Denda atau dampak hukum lainnya dapat terjadi karena pelanggaran kontrak, hukum, atau peraturan lainnya.

Kerugian Tidak Langsung: Hilangnya Kredibilitas: Orang akan kehilangan kepercayaan dalam bisnis yang memiliki masalah keamanan, bahkan jika masalah keamanan tidak menyebabkan kerugian atau kerusakan apa pun.

Hilangnya Produktivitas: Tidak tersedianya sistem e-commerce dapat mengakibatkan kerugian produktivitas karena karyawan tidak akan dapat bekerja selama waktu henti. .

Pengungkapan informasi rahasia: Rahasia bisnis dapat dicuri juga informasi karyawan dan pelanggan. 
Pemerasan: Penyerang yang jahat dapat mengambil alih sistem dan menuntut kompensasi kepada mengembalikan server ke kendali bisnis.

Masalah teknis: - Kerusakan pada file atau sistem: Kompromi keamanan dapat mengakibatkan kerusakan pada file atau sistem secara keseluruhan. File bisa hilang dan server bahkan bisa dirusak oleh orang jahat menyerang.

Kesalahan dalam konfigurasi: Beberapa serangan berbahaya dapat mengkonfigurasi ulang sistem untuk melakukan dengan cara yang berbeda dari biasanya.

Kesalahan dalam aplikasi: Aplikasi pada server bisa memiliki kesalahan dan tidak berfungsi tepat.

\subsection{Serangan Dan Kerentanan}

Setiap hari, berbagai jenis kejahatan teknologi sedang dilakukan, yang dapat menyebabkan banyak hal masalah bagi para korban. Kejahatan teknologi terjadi di sekitar kita, tetapi kurang terlihat dan kurang pribadi dari kejahatan lainnya. Harris dan Patten (2014) menyoroti dilema yang dihadapi oleh usaha kecil dan menengah dalam menerapkan kontrol yang muncul untuk smartphone dan tablet. Harris dan Patten membahas bahwa usaha kecil dan menengah tidak memiliki kemampuan keuangan yang sama yang dimiliki perusahaan skala besar untuk mengimbangi ancaman yang muncul ini. Tidak mungkin bagi penjahat untuk tertangkap karena mereka tidak harus mengambil resiko seorang tetangga melihat mereka atau alarm yang berbunyi akan meledak. Anonimitas dan ketersediaan internet telah mempermudah hacker jahat untuk melakukan kejahatan dan tidak mendapatkan tertangkap.

Kejahatan teknologi juga memiliki pembayaran yang lebih besar di sebagian besar waktu daripada kejahatan tradisional. Teknik canggih dan cerdik telah memungkinkan penjahat zaman modern ini untuk menggunakan ribuan identitas curian untuk menghabiskan miliaran dari bank dan lembaga keuangan lainnya. Sementara itu, Rata-rata orang stick up mendapat sekitar \$ 7.200 dalam perampokan bank "(Segal, A., \& Thorne, J., 2006). Ini penting untuk memahami metode penyerangan agar dapat secara efektif mengetahui dan memahami cara melakukannya lindungi mereka. Metode penyerangan terus berubah, jadi penting untuk tetap mengikuti perkembangan alat dan teknik terbaru yang digunakan peretas jahat untuk menembus pertahanan jaringan juga sebagai kebutuhan perlindungan terbaru.

\subsection{Ancaman Server Web}

Perangkat lunak server web dirancang untuk mengirim halaman web dengan menanggapi permintaan HTTP. Web perangkat lunak server biasanya dirancang untuk kegunaan dan kenyamanan, bukan keamanan. Hal itu semakin kompleks perangkat lunak, semakin besar probabilitas yang mengandung kesalahan atau keamanan pengkodean kelemahan (Schneider, 2009). Semakin banyak baris kode, semakin besar peluang yang akan terjadi kesalahan. Perkiraan umum yang digunakan dalam industri ini adalah bahwa terdapat antara 5-50 bug per 1.000 baris kode. Jadi perkiraannya adalah Windows 7 memiliki sekitar 1.200.000 bug (Elang, Harper, Harris, Ness, \& Williams, 2011). Pada 2013, ada lebih dari 103.000 eksploit terbuka terkait dengan Linux, sistem operasi yang populer (Avgerinos et al., 2014). Pada 2015, ada lebih dari 100.000 insiden yang dikonfirmasi 
dengan 2.164 pelanggaran data yang dilaporkan yang melibatkan perusahaan-perusahaan Amerika Serikat (Verizon, 2016). Dengan Linux sebagai open source, ini adalah pilihan populer untuk usaha kecil dan perusahaan yang di-outsource oleh usaha kecil (Avgerinos et al., 2014).

Server web dapat dikompromikan oleh penyerang yang mendapatkan nama pengguna dan kata sandi salah satu para pengguna. Setelah penyerang memiliki nama pengguna dan kata sandi, dia kemudian dapat memperoleh akses dan meningkatkan hak istimewa sehingga ia dapat memiliki akses tanpa batas ke server. Penyerang kemudian dapat menginstal backdoor agar dia dapat memperoleh akses di masa depan.

Server web juga tunduk pada serangan fisik. Seseorang bisa mendapatkan akses ke ruangan di mana server berada dan menyebabkan kerusakan. Setelah seseorang memiliki kontrol fisik atas server, dia mampu melakukan hampir semua hal dengan itu.

\subsection{Ancaman Database}

Sistem Perdagangan Elektronik menyimpan data pengguna dan mengambil informasi produk dari basis data terhubung ke server web. Basis data juga mengandung informasi berharga yang merupakan target besar untuk sebuah serangan. Trojan horse dapat mengubah hak akses atau menghapus kontrol akses untuk memberi pengguna akses tak terbatas.

\subsection{Pengintaian}

Mendapatkan sebanyak mungkin informasi tentang jaringan target adalah penting untuk melaksanakan yang efektif menyerang. Anda perlu mengetahui jenis sistem operasi apa yang sedang dijalankan mesin, apa port terbuka dan kerentanan sistem target. Mengetahui semua informasi itu membuatnya lebih mudah untuk melakukan serangan.

\subsection{Rekayasa Sosial}

Rekayasa sosial adalah bentuk penipuan di mana seseorang berpura-pura menjadi seseorang yang bukan dirinya dan mencoba untuk menyusup ke fasilitas atau mendapatkan informasi. Rekayasa sosial dapat menjadi cara termudah untuk mendapatkan akses ke akun, sistem atau fasilitas dan tidak memerlukan banyak pengetahuan teknis. "Itu a trik hacker umum untuk menelepon karyawan yang tidak curiga dan berpura-pura menjadi sistem jaringan administrator atau manajer keamanan. Jika peretas cukup tahu tentang jaringan perusahaan terdengar meyakinkan, dia bisa mendapatkan kata sandi, nama akun, dan informasi sensitif lainnya (Schneier, B., 2004). Ini juga bisa dilakukan secara langsung atau melalui telepon dan peretas bias mendapatkan akses ke dan akun atau area aman di fasilitas.

\subsection{Pemindaian Port}

Setelah semua informasi tentang sistem telah diambil melalui rekayasa sosial atau cara lain, pemindaian port digunakan untuk menentukan port yang terbuka pada sistem. Setiap TCP / IP protokol memiliki beberapa ribu port, yang membantu komunikasi ke 
internet. Membuka port seperti pintu atau jendela terbuka untuk rumah Anda. Pemindai port digunakan untuk memindai port sebuah sistem dan menghasilkan laporan kepada pengguna tentang status port. Pemindai port mengirim pesan ke komputer yang meminta akses ke setiap port. Port kemudian mengirim sinyal kembali ke pemindai port dan pemindai dapat menentukan status port tersebut dengan pesan itu. Ini mirip dengan pemeriksaan kriminal semua pintu atau jendela ke rumah Anda dalam upaya untuk menemukannya yang dibuka sehingga dia dapat memperoleh akses ke rumah Anda.

\subsection{Pemindaian Kerentanan}

Pemindaian kerentanan adalah bagian penting dari serangan karena menunjukkan kelemahan yang berbeda dari sistem target. "setelah serangkaian" pada jaringan yang dapat diakses (port) telah diidentifikasi untuk sekumpulan sistem target dan informasi aplikasi terkait apa pun, 'langkah' berikutnya di eksekusi serangan biasanya untuk memulai proses identifikasi sistem operasi tertentu dan kerentanan aplikasi "(Young, S., 2004). Program komputer dibangun dengan kegunaan dalam pikiran dan fokus menjauh dari keamanan. Setiap program memiliki beberapa kerentanan yang membuatnya rentan terhadap serangan. Setelah kelemahan ditentukan, seorang hacker bisa mengambil keuntungan dan memodifikasinya, yang dapat menyebabkan kerusakan pada program atau sistem.

\subsection{Serangan Server E-commerce}

Sekarang semua informasi telah dikumpulkan, serangan yang sebenarnya dapat terjadi. Penyerang harus merencanakan serangannya berdasarkan keterampilan, peralatan, dan pengetahuan yang dimilikinya. Peretas memiliki banyak motif berbeda untuk menyerang jaringan dan tidak semuanya berbahaya. Beberapa peretas menyerang jaringan untuk mengeksploitasi kelemahan dan kemudian memperbaiki kelemahan itu untuk kompensasi. Lain peretas menyerang jaringan untuk menguji keterampilan mereka, sementara yang lain ingin mencuri informasi.

\subsection{Serangan Fisik}

Serangan fisik tidak membutuhkan banyak pengetahuan teknis tetapi bisa sama merusaknya dengan yang lain serangan. Serangan fisik memerlukan akses fisik ke jaringan, yang biasanya dilakukan oleh orang dalam atau insinyur sosial. Setelah seseorang memperoleh akses fisik ke server, dia dapat memilikinya kontrol penuh atas sistem itu. Mencegah seseorang dari mendapatkan akses fisik ke server adalah mungkin yang paling penting, tetapi hampir tidak mungkin. Peretas yang berbahaya juga mungkin karyawan yang memiliki dendam terhadap perusahaan dan ingin merugikan perusahaan itu; mereka bahkan bias administrator jaringan atau keamanan.

\subsection{Malware}

Program malware, juga dikenal sebagai perangkat lunak berbahaya, dibangun untuk secara rahasia menginfeksi target komputer saat membuka program. Malware termasuk virus, Trojan horse, worm, dan rootkit dan perangkat lunak lainnya dengan niat jahat. 
Program malware dapat disamarkan sebagai perangkat lunak yang sah tetapi dapat menyebabkan kerusakan setelah pemasangan.

Virus komputer dan worm adalah jenis malware yang paling umum. Virus adalah program itu menginfeksi perangkat lunak yang dapat dieksekusi dan menyebar ke perangkat lunak yang dapat dijalankan lainnya saat program dijalankan.

Secara tradisional, worm komputer dianggap sebagai aplikasi yang dapat mereplikasi dirinya melalui koneksi jaringan permanen atau dial-up. Tidak seperti virus, yang menabur sendiri di dalam hard disk atau sistem file komputer, worm adalah program mandiri (Brenton, C., 2003). Trojan horse dan rootkit adalah perangkat lunak nondestruktif, yang memungkinkan akses remote dan hacker hak akses administratif. Trojan horse memungkinkan pengguna terus mengakses sistem tetapi hanya mengizinkan hak pengguna peretas. Rootkit memungkinkan hacker untuk memiliki akses berkelanjutan ke target sistem dan hak administratif. Trojan horse dan rootkit digunakan untuk penolakan serangan layanan, pencurian data, memodifikasi file, penebangan kunci atau pemantauan komputer. Mereka juga digunakan untuk membuat komputer zombie, yang digunakan untuk menyerang komputer lain.

\subsection{Penolakan Layanan}

Banyak perusahaan menjalankan dan mengandalkan jaringan mereka untuk kebutuhan bisnis mereka. Beberapa perusahaan menggunakan jaringan mereka untuk mengirim file dan yang lain menggunakannya untuk menjual produk. Dalam serangan denial of service (DOS), a hacker membanjiri jaringan dengan begitu banyak informasi yang menyebabkan kelebihan beban dan mematikan sistem. Nama serangan mengatakan itu semua dan menjelaskan apa tujuan dari serangan DOS adalah; untuk mematikan layanan perusahaan.

\section{Metode Proteksi}

Keamanan komputer dan informasi sangat penting untuk bisnis, keluarga dan individu untuk tetap dilindungi dari peretas yang berbahaya, seniman scam, dan pemangsa online. Dengan semua kejahatan itu mungkin, keamanan jaringan harus menjadi perhatian utama bagi semua orang, tanpa memandang status. Jika informasi tidak disengaja atau dengan sengaja dihapus, dimodifikasi atau dicuri, itu dapat menempatkan bisnis itu keluar dari layanan untuk jangka waktu yang panjang atau bahkan tanpa batas. Menjaga kerahasiaan, integritas dan ketersediaan dalam bahasa inggris dikenal dengan confidentiality, integrity and availability (CIA) adalah tujuan utama keamanan jaringan. Berbagai jenis keamanan diperlukan untuk mencapai tujuan CIA dan menyediakan sistem perlindungan yang menyeluruh. Metode-metode itu mungkin mahal tetapi bisa sepadan tergantung pada risiko serangan. Sementara itu mustahil untuk membuat tambalan untuk perlindungan program lengkap, masih perlu untuk menerapkan pembaruan terbaru dan menginstal tambalan agar lebih sulit bagi peretas untuk menerapkan serangan. 


\subsection{Standar Keamanan E-Commerce}

Bisnis, kecil dan besar, harus mematuhi hukum dan peraturan tertentu yang terkait kegiatan mereka. Perhatian terhadap keamanan telah menyebabkan pengembangan standar dan peraturan untuk melindungi data berharga.

\subsection{ISO 17799}

ISO mengadopsi standar yang awalnya diterbitkan oleh British Standard Institute (BSI). BSI mengeluarkan BS7799 pada tahun 1998 dan kemudian diadopsi oleh ISO sebagai 17799. ISO 17799 menyediakan rekomendasi untuk hal berikut:

Klasifikasi Aset dan Pengendalian- Semua aset informasi harus dipertanggung jawabkan dan memiliki klasifikasi keamanan untuk menunjukkan kebutuhan dan prioritas untuk perlindungan.

Personil keamanan- Personel harus diberikan pendidikan keamanan yang sesuai dan menjadi mengetahui prosedur pelaporan insiden.

Keamanan Fisik dan Lingkungan $\cdot$ Keamanan jaringan $\cdot$ Kontrol akses

\subsection{Kebijakan Keamanan}

Organisasi apa pun yang peduli dengan melindungi aset perdagangan elektroniknya harus memiliki keamanan kebijakan di tempat. Kebijakan keamanan harus menggambarkan aset mana yang harus dilindungi dan mengapa, siapa bertanggung jawab atas perlindungan mereka, dan apa yang dapat diterima dan apa yang tidak. Kebijakan keamanan bertindak sebagai membimbing karyawan agar mereka tahu apa yang harus dilakukan sebelum, selama, dan setelah insiden. Para karyawan semua harus menyadari kebijakan, dan tes dapat dilakukan untuk memastikan kompetensi mereka. Tes bisa dalam berbagai bentuk, seperti tes tertulis, lisan dan berbasis skenario. Tes seharusnya dirancang agar karyawan merasa nyaman dengan informasi dalam kebijakan dan nyaman menanggapi berbagai situasi.

\subsection{Keamanan Fisik}

Keamanan fisik harus menjadi jenis keamanan pertama yang diterapkan. Itu tidak masuk akal mengamankan komputer Anda dan meninggalkan tempat Anda tidak aman; itu hampir sama dengan mengunci pintu ke rumah Anda tetapi membiarkan jendela terbuka. Keamanan fisik bahkan bisa dalam bentuk video sistem pemantauan dan perangkat kontrol akses. Meskipun tidak ada cara untuk sepenuhnya aman, itu yang terbaik adalah membatasi kemungkinan menjadi korban.

\subsection{Kontrol Akses}

Mengontrol akses ke fasilitas atau wilayah di fasilitas merupakan bagian penting dari keamanan. Keamanan penjaga harus digunakan untuk melakukan patroli keliling dan verifikasi ID karyawan. Masalah dengan penjaga keamanan adalah bahwa mereka adalah 
rekayasa sosial dan manusia yang dapat digunakan untuk memanipulasinya. Karena masalah rekayasa sosial, kunci, pemindai biometrik, dan kata sandi seharusnya juga dipertimbangkan untuk kontrol akses.

\subsection{Pemantauan}

Pemantauan sangat penting karena peretas dapat menyelinap masuk tanpa sepengetahuan dan menyebabkan banyak kerusakan. Fasilitas dan jaringan perlu dimonitor untuk mencegah peretas dari pertahanan menembus dan menyebabkan kerusakan ireversibel. Dengan pemantauan konstan, keamanan akan dapat mendeteksi serangan dan menghentikannya sebelum kerusakan terjadi. Lebih baik mengambil tindakan mencegah sesuatu terjadi daripada mencoba memperbaiki kerusakan nanti. Beberapa hal mungkin rusak diperbaiki dan informasi penting bisa hilang selamanya.

\subsection{Autentikasi}

Metode verifikasi yang berbeda digunakan oleh berbagai lembaga untuk mencegah pengguna yang tidak sah dari mengakses fasilitas, sistem, dan layanan mereka.

\subsection{Biometrik}

Biometrik menggunakan tubuh seseorang untuk verifikasi akses. Pemindaian retina, sidik jari dan telapak tangan pembaca, dan pemindai tubuh lainnya digunakan untuk kontrol akses untuk memverifikasi identitas seseorang. Biometrik itu bagus karena menggunakan bagian-bagian tubuh yang unik bagi individu itu. Itu masalah dengan biometrik datang ketika seseorang merusak bagian tubuh mereka yang digunakan untuk verifikasi. Jika seseorang merusak bagian tubuh yang digunakan untuk verifikasi, itu akan membutuhkan kerja ekstra dan administrator harus menggunakan cara yang berbeda untuk memungkinkan orang itu mengakses.

\subsection{Nama Pengguna dan Kata Sandi}

Nama pengguna dan kata sandi adalah kredensial yang dipilih pengguna, yang biasanya memiliki persyaratan tertentu yang diatur oleh administrator. Persyaratan harus ditetapkan karena orang akan menggunakan kata sandi yang umum dan peretas dapat merusaknya. "Kata sandi paling aman setidaknya 8 karakter panjang dengan campuran huruf besar dan huruf kecil dan simbol dan angka. Itu lagi panjang kata sandi, dan semakin acak pemilihan karakter dan angka, kata sandinya lebih kuat "(Failor, D., 2009). Masalah dengan kata sandi dan nama pengguna adalah itu orang-orang melupakan mereka atau mereka menuliskannya dan menempatkannya di tempat di mana orang dapat menemukannya mereka.

\subsection{Smartcards}

Smartcards digunakan di banyak fasilitas untuk mengontrol akses ke area, sistem, atau layanan tertentu. Smartcards memungkinkan akses seseorang tanpa harus mengingat kata sandi. Masalah dengan banyak smartcards adalah bahwa orang kehilangan mereka dan orang lain mungkin bisa menggunakannya. 


\subsection{Keamanan Nirkabel}

Hari-hari menghubungkan komputer dengan kabel hilang; sekarang bisnis menggunakan koneksi nirkabel untuk mengirim, menerima, dan mengakses informasi. Mengirim dan menerima informasi secara nirkabel membuatnya rentan untuk ditangkap. Sistem dapat mengirim dan menerima informasi melalui router nirkabel yang terhubung ke modem yang terhubung ke Internet. Komputer mengirim paket ke router nirkabel, yang kemudian mentransfernya ke modem dan melalui Internet.

\subsection{1X Standar}

802.11 menyediakan akses nirkabel ke jaringan kabel. "Kerangka keseluruhan untuk menyediakan akses kontrol untuk jaringan adalah apa yang disebut sebagai sistem otentikasi berbasis port, yang beberapa orang menyebut sebagai 802.1X "(Geier, 2008). Karena keamanannya yang ditingkatkan, 802.1x adalah standar nirkabel yang direkomendasikan. "Otentikasi nirkabel terkuat saat ini tersedia, otentikasi IEEE 802.1x menyediakan otentikasi yang paling kuat untuk WPA2 Model Enterprise WLAN "(Ciampa, 2009). 802.1x menyediakan fitur kontrol akses seperti MAC Alamat penyaringan, kunci enkripsi akses WPA2, dan Kemampuan untuk mematikan siaran SSID. Meskipun 802.1x adalah standar nirkabel yang disarankan karena keamanan, masalah dengan $802.1 \mathrm{x}$ adalah biaya untuk menerapkan dan memelihara.

\subsection{Kriptografi}

Kriptografi digunakan untuk mengubah plaintext menjadi suatu algoritma yang dikenal sebagai ciphertext, yang merupakan kompleks urutan matematis yang tidak terbaca kepada siapa pun tanpa kode untuk menguraikannya. Setelah data dienkripsi ke dalam ciphertext, diberikan kata sandi dan kata sandi diperlukan untuk mendekripsi data dan mengubahnya kembali menjadi plaintext. Data itu dapat dikirim ke orang lain selama orang itu kata sandi untuk mendekripsi informasi. Jenis algoritma menentukan kekuatan dari enkripsi dan dapat membuatnya lebih atau kurang sulit untuk didekripsi tanpa kunci yang tepat.

Kriptografi juga digunakan untuk membuat tanda tangan untuk dokumen, yang membantu menentukan orisinalitas dari dokumen itu.

\subsection{Hashing}

Hashing adalah cara membuat tanda tangan yang unik untuk dokumen untuk membuktikan bahwa dokumen itu adalah dokumen asli. Ini penting untuk mencegah seseorang menyalin dokumen. Jika seseorang digunakan untuk membandingkan dengan dokumen untuk memastikan itu asli. Jenis hash yang paling aman adalah Secure Hash Algorithm (SHA), yang menggunakan enkripsi 160 bit.

\subsection{Simetris}


Enkripsi simetris menggunakan kunci tunggal untuk mengenkripsi dan mendekripsi data dan mengganti setiap huruf dan nomor dalam dokumen dengan yang lain dalam urutan acak sehingga hampir tidak mungkin untuk memecahkan kode tanpa kunci. Advanced Encryption Standard (AES) adalah yang paling terkini dan paling aman enkripsi simetris di pasaran. "Setelah proses panjang yang membutuhkan kerja sama pemerintah AS, industri, dan pendidikan tinggi, lima finalis dipilih, dengan yang paling utama pemenang menjadi algoritma yang dikenal sebagai Rinjdael, yang lebih sering disebut sebagai AES "(Ciampa, M., 2009). Masalah dengan enkripsi simetrik adalah bahwa ia menggunakan kunci tunggal, yang dilewatkan sekitar dan diharapkan untuk tetap aman.

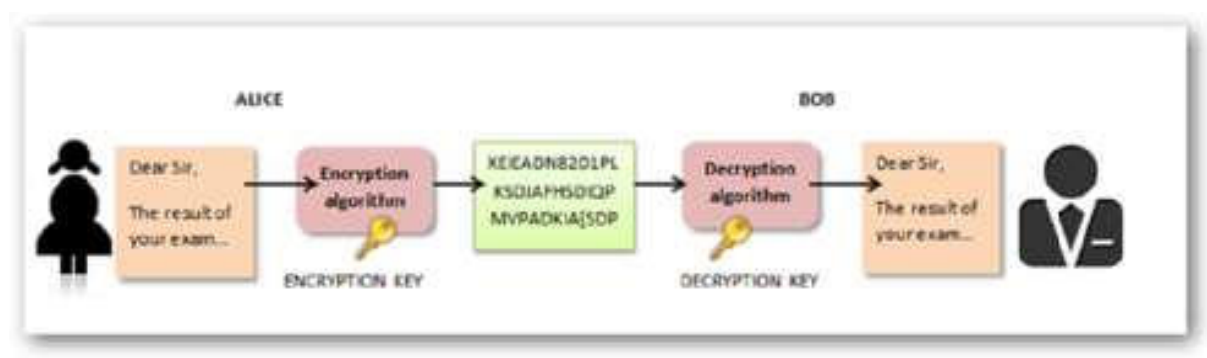

\subsection{Asimetris}

\section{Gambar 2. Enkripsi Symmetric}

Meskipun keduanya masih digunakan saat ini, kriptografi asimetris jauh lebih aman daripada simetris kriptografi. Cipher asimetris jauh lebih rumit secara matematis daripada simetris ciphers (Dent, A., Mitchell, C., 2005). Tidak seperti kriptografi simetris, asimetris kriptografi memiliki lebih dari satu kunci, yang dikenal sebagai kunci publik dan pribadi. Itu beberapa kunci baik untuk alasan keamanan tetapi dapat membingungkan pada mana yang digunakan.

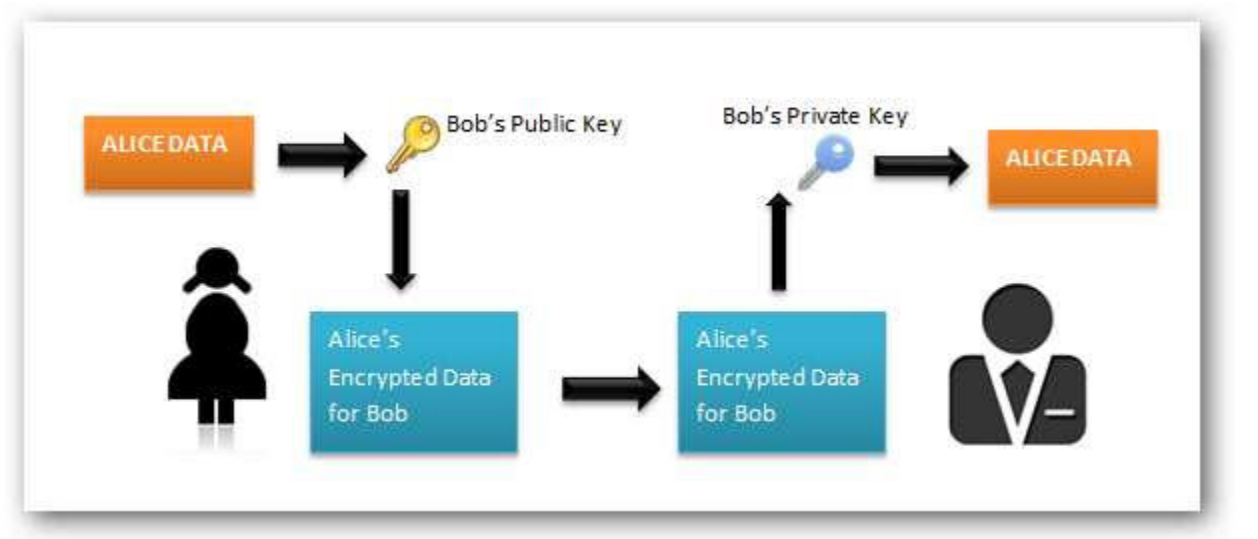

Gambar 2. Enkripsi Asymmetric

\subsection{EAP-TLS (Transport Layer Security)}

EAP-TLS umumnya dianggap sebagai yang terkuat dan paling mahal untuk diterapkan. Menyediakan otentikasi sertifikat bersama antara klien dan server, menggunakan TLS standar protokol (turunan dari protokol SSL yang digunakan untuk mengamankan sebagian besar transaksi Web). "Ini adalah sebuah protokol klien / server yang ditumpuk 
di atas protokol lapisan transport yang dapat diandalkan, seperti TCP di kasus TCP / IP dan terdiri dari dua lapisan dan protokol yang sama dengan SSL "(Oppliger, R., 2009). Server menggunakan TLS untuk menunjukkan bahwa ia memegang sertifikat digital dan meminta hal yang sama dari klien. Klien menggunakan sertifikatnya untuk membuktikan identitas dan material kunci ditukar. Tunneled TLS berakhir setelah otentikasi selesai. Kunci yang dikirim oleh EAP-TLS dapat digunakan untuk mengenkripsi data dengan Advanced Encryption Standard (AES), Temporal Protokol Integrasi Utama (TKIP) atau Wired Equivalent Privacy (WEP). EAP-TLS cocok WLAN di mana klien sudah memiliki sertifikat digital atau di mana keamanan tinggi perlu dibenarkan investasi dalam infrastruktur kunci publik untuk mengelola sertifikat tersebut.

\subsection{EAP-TTLS (Tunneled TLS)}

Jenis EAP ini menyeimbangkan keamanan vs. biaya pemasangan dengan mengganti sertifikat sisi klien dengan metode otentikasi kata sandi lama seperti PAP, CHAP dan MSCHAPv2. EAP-TTLS membutuhkan server untuk mengotentikasi dirinya sendiri dengan sertifikat dan membangun terowongan TLS yang dilalui tantang klien. Terowongan TLS digunakan untuk melindungi metode otentikasi internal yang kurang aman. Bahkan ketika kata sandi teks yang jelas dikembalikan, Tunneled TLS mengaburkan respons klien. Untuk menghindari memaparkan nama klien, EAP-TTLS harus dikonfigurasi untuk mengirim "anonim" identitas ketika 802.1X dimulai, kemudian kirim identitas sebenarnya melalui terowongan TLS. Tunneled itu berakhir saat otentikasi selesai dan kunci dikirim. "EAP-TTLS telah banyak dikerahkan, dan kemungkinan akan dihadapi di banyak WLAN perusahaan. Sedangkan EAP-TTLS adalah hampir identik dengan EAP-PEAP, itu tidak menikmati dukungan asli untuk operasi Windows sistem, yang telah menghasilkan penetrasi pasar yang relatif lebih sedikit "(Wescott, D., 2010).

\subsection{WPA2 AES Passphrase}

Pre-shared Key mode (PSK) tidak memerlukan kompleksitas dari server otentikasi 802.1x. Setiap perangkat jaringan nirkabel mengenkripsi lalu lintas jaringan menggunakan kunci 256-bit. Kunci ini mungkin masuk baik sebagai string 64 digit hex, atau sebagai passphrase dari 8 hingga 63 karakter ASCII. "Di kriptografi, Advanced Encryption Standard (AES) adalah standar enkripsi kunci simetris diadopsi oleh pemerintah AS. Standar ini terdiri dari tiga blok cipher, AES-128, AES-192 dan AES256, diadopsi dari koleksi yang lebih besar yang aslinya diterbitkan sebagai Rijndael. Masing-masing ini cipher memiliki ukuran blok 128-bit, dengan ukuran kunci 128, 192 dan 256 bit, masing-masing " (Mcbrewster, Miller, \& Vandome, 2009). The AES cipher telah dianalisis secara luas dan sekarang digunakan di seluruh dunia, seperti halnya dengan pendahulunya, Standar Enkripsi Data (DES).

\subsection{Sertifikat Digital}

Sertifikat digital menyatakan kepemilikan kunci publik dengan subjek bernama dari sertifikat. Ini Memungkinkan orang lain untuk mengandalkan tanda tangan atau pernyataan yang dibuat oleh kunci pribadi itu sesuai dengan kunci publik yang disertifikasi. Dalam model hubungan kepercayaan ini, CA adalah a pihak ketiga tepercaya yang dipercaya oleh subjek (pemilik) sertifikat dan pihak tersebut mengandalkan sertifikat 
(IBM, n.d.). Sertifikat digital digunakan untuk berkomunikasi Internet menggunakan protokol aman seperti HTTPS.

\subsection{Firewall}

Firewall adalah konfigurasi perangkat lunak atau perangkat keras. Tujuan utama firewall adalah mengontrol lalu lintas jaringan internal inbound dan outbound. Seharusnya memberi atau menolak akses ke pribadi jaringan. Firewall dapat digunakan untuk membatasi sistem dari hanya menyediakan sejumlah kecil layanan. Ada tiga jenis firewall:

Packet filtering firewall- Ini memeriksa sumber dan alamat tujuan dari paket-paket. Mereka memastikan paket yang diterima dari luar berada di dalam Menanggapi yang dikirim.

Firewall gerbang proxy-Ini bertindak sebagai gateway untuk pengguna luar menghubungkan ke jaringan. Pengguna luar pertama harus terhubung ke firewall gateway sebelumnya dapat terhubung ke jaringan. Aplikasi proxy firewall-Ini memeriksa a permintaan pengguna untuk terhubung ke server aplikasi.

Mereka memastikan bahwa permintaan pengguna sesuai dengan yang ada pada protokol aplikasi.

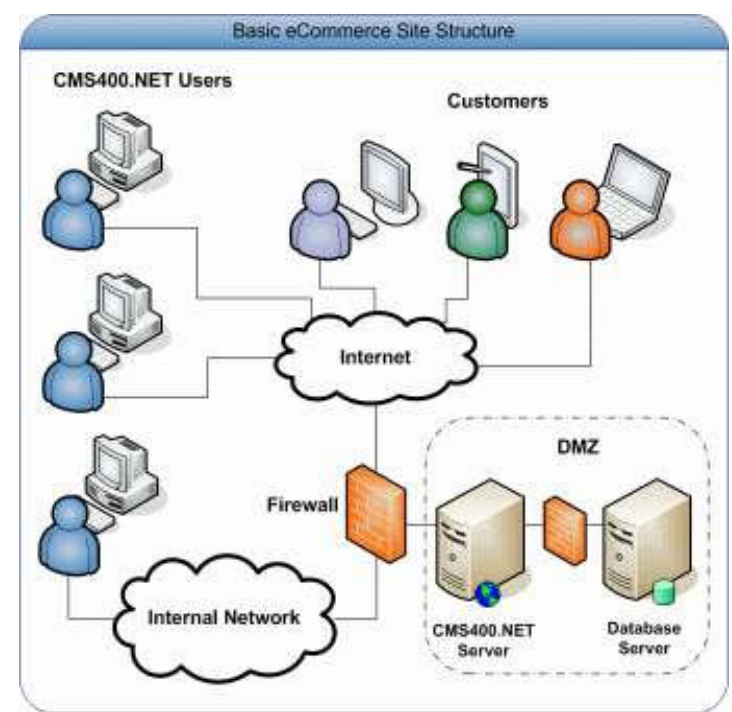

Gambar 4. Struktur Situs E-commerce Dasar

Komponen sistem e-commerce harus dikonfigurasi untuk memungkinkan sistem atau server aktif jaringan internal untuk memulai koneksi dengan jaringan. Firewall dapat digunakan untuk batasi server atau sistem di jaringan dari memulai koneksi ke jaringan internal.

\subsection{Sistem Deteksi dan Pencegahan Komputer}

Sistem Deteksi dan Pencegahan Intrusi Komputer mirip dengan memiliki detektor gerakan membangun dan mengunci pintu dan jendela. Deteksi Intrusion atau Intrusion 
Detection System (IDS), mirip dengan detektor gerak, Dimaksudkan untuk mendeteksi penyerang potensial dan memperingatkan seseorang mengambil tindakan. The Intrusion Prevention System (IPS), mirip dengan kunci pada pintu dan windows, dimaksudkan untuk menjaga penyerang keluar. Nama-nama kedua sistem itu merangkum apa mereka dimaksudkan untuk. Untuk memiliki program keamanan yang baik, Anda membutuhkan kedua system perlindungan; satu untuk deteksi dan yang lainnya untuk mencegah aktivitas jahat. Banyak sistem hari ini menggabungkan deteksi dan pencegahan ke dalam satu sistem dan dikenal sebagai Deteksi Intrusion dan Sistem Pencegahan atau Intrusion Detection and Prevention Systems (IDPS).

\subsection{Sistem Pencegahan Intrusi}

IPS menggunakan protokol tertentu untuk mengidentifikasi ancaman dan mencegah mereka mengakses jaringan sehingga mereka tidak memiliki kesempatan untuk merusak sistem. IPS memantau lalu lintas jaringan untuk berbahaya aktivitas, catat aktivitas, usahakan untuk mencegahnya mengakses jaringan, dan kemudian laporkan aktivitas ke administrator sehingga dia dapat menindaklanjuti dengan tindakan. Sama seperti IDS, IPS dapat mendeteksi aktivitas yang tidak berbahaya dan administrator harus memutuskan apa yang harus dilakukan

\subsection{Sistem Operasi}

Dalam sistem e-commerce, penting untuk mengurangi kemungkinan serangan dengan mengurangi atau menghilangkan sebanyak mungkin kerentanan. Ini dilakukan dengan memasukkan IDS, memasang sistem anti-virus, menghapus semua program yang tidak perlu, menutup semua port dan mengonfigurasinya untuk melindungi dari akses yang tidak sah. "Dalam banyak contoh, sistem operasi menyediakan gateway ke dalam sistem komputer karena banyaknya port terbuka dan layanan berjalan. Jalur ini merupakan sumber potensial serangan ke sistem perdagangan Web ”(Nahari, \& Krutz, 2011).

\subsection{Otomasi Keamanan}

Untuk sebagian besar bisnis kecil, tidak ada cukup orang untuk secara efektif mengelola sistem e-commerce. Banyak pemilik usaha kecil, mengalihdayakan atau mengontrak manajemen e-commerce mereka sistem. Banyak perusahaan menawarkan opsi untuk meng-host sistem e-commerce untuk usaha kecil, tetapi mungkin penting bagi beberapa pemilik bisnis untuk memiliki segalanya di rumah. Jika usaha kecil ingin memiliki dan mengelola server mereka sendiri dan sistem e-commerce, penting untuk keamanan set-up yang dijalankan terutama oleh perangkat lunak. Banyak jenis perangkat lunak keamanan bisa dikonfigurasi untuk mendeteksi dan secara otomatis menangani insiden yang dicurigai. Penting untuk dicari perangkat lunak yang memiliki false-positif rendah karena berpotensi melukai bisnis jika memblokir transaksi dari yang terjadi alih-alih memblokir percobaan serangan. Juga, penting untuk ditemukan perangkat lunak yang memiliki tim yang bagus dan menawarkan pembaruan berkelanjutan.

Ancaman terus berkembang dan penting bagi perusahaan perangkat lunak untuk selalu mengikuti perkembangan terbaru terhadap ancaman mereka perangkat lunak. Penting 
untuk terus memeriksa pembaruan dan agar kerentanan perangkat lunak diperbaiki sebelum serangan terjadi.

\section{Kesimpulan}

E-commerce adalah sebuah cara efektif untuk berbisnis. Ini memungkinkan bisnis untuk menyediakan produk dan layanan untuk populasi yang lebih luas daripada yang mereka bisa dengan operasi batu bata dan mortir radisional. Namun, e-commerce juga hadir dengan berbagai risiko yang perlu dimitigasi beroperasi dengan aman. Usaha kecil memberikan target yang mudah bagi penyerang karena biasanya memiliki dana terbatas dan tidak memiliki profesional jaringan khusus untuk memantau dan melindungi jaringan mereka. Peretas memiliki berbagai macam alat yang memungkinkan mereka untuk menyerang jaringan bahkan dengan sedikit pengetahuan teknis. Peretas menggunakan sistem bersama dengan alat mereka untuk menyerang sistem. Pertama perlu mengumpulkan sebanyak mungkin informasi tentang sistem target, memindai port terbuka, memindai kerentanan dan kemudian melakukan serangan mereka. Seiring dengan serangan teknis, beberapa penyerang mungkin mencoba serangan fisik melalui rekayasa sosial dan mendapatkan akses ke bisnis server dengan berpura-pura menjadi seseorang yang bukan mereka.

Usaha kecil perlu mengambil tindakan pencegahan sebanyak mungkin untuk melindungi sistem mereka, bahkan jika itu berarti menghabiskan uang ekstra untuk melakukannya. Melihat kondisi tersebut maka tidak ada cara untuk benar-benar mengamankan jaringan, tetapi ada beberapa cara untuk memperkecil kemungkinan menjadi korban. Membatasi peluang menjadi korban lebih baik daripada mencoba memperbaiki kerusakan setelah serangan, yang mungkin tidak dapat diperbaiki. Serangan datang dalam berbagai bentuk, jadi sangat penting untuk memastikan keamanan sebanyak itu langkah-langkah diletakkan di tempatnya mungkin. Pelaksanaan berbagai langkah pengamanan adalah penting untuk perlindungan keluarga, kelangsungan bisnis dan keamanan nasional. Dengan hasil yang mungkin dari serangan pada jaringan, bisnis harus sangat memperhatikan keamanan jaringan secara serius dan benar melindungi sistem mereka.

\section{Daftar Pustaka}

[1] Avgerinos, T., Sang Kil, C., Rebert, A., Schwartz, E. J., Woo, M., \& Brumley, D. (2014). Automatic exploit generation. Communications of the ACM, 57(2), 74-84. http://dx.doi.org/10.1145/2560217.2560219

[2] Brenton, C. (2003). Mastering Network Security. 2nd ed. Alameda, CA: Sybex.

[3] Ciampa, M. (2009). CompTIA Security+ 2008 In Depth. Boston, MA: Course Technology.

[4] Dell (1999), How Stuff Works, available at: www.howstuffworks.com

[5] Fletcher, R., Bell, J., \& McNaughton, R. (2004) International E-business Marketing. 1st ed. Cornwall: TJ International Ltd.

[6 Harris, M. A., \& Patten, K. P. (2014). Mobile device security considerations for smalland medium-sized enterprise business mobility. Information Management \& Computer Security, 22(1), 97-114. http://dx.doi.org/10.1108/IMCS-03-2013-0019

[7] IBM (n.d.). Installing GUI Certificates. Retrieved from: http://www01.ibm.com/support/docview.wss?uid=swg21516057 
[8] Kalakota, R. and Whinston, A. (1997), Electrnic Commerce: A Manager's Guide, Addison-Wesley, Reading, MA.

[9] Lawson, R., Cooper, J. and Alcock, C. (1999), Business on-line: manufacturing small and medium Enterprises in south west Sydney, in CollECTeR '99 Conference Proceedings, December.

[10] Mcbrewster, J., Miller, F., \& Vandome, J. (2009). Advanced Encryption Standard. Alphascript Publishing.

[11] Nahari, H., \& Krutz, R. (2011). Web Commerce Security: Implementation and Design. Wiley Publishing.

[12] Oppliger, R. (2009). SSL and TLS: Theory and Practice. Artech House.

[13] Pawar, K. and Driva, H. (2000), Electronic trading in the supply chain: a holistic implementation framework, Logistics Information Management, Vol. 13 No. 1, pp. 21-32

[14] Radstaak, B. and Ketelaar, H. (1998), Worldwide Logistics: The Future of supply chain Services, Holland International distribution council, The Hague

[15] Rahman, S., \& Lackey, R. (2013). E-Commerce systems security for small businesses. International Journal of Network Security \& Its Applications, 5(2), 193-210. http://dx.doi.org/10.5121/ijnsa.2013.5215

[16] Roos, D. (n.d.). The History of E-Commerce. Retrieved from: http://money.howstuffworks.com/history-e-commerce1.htm.

[17] Segal, A. \& Thorne, J. (2006). Identity Theft: The New Way to Rob Banks. Retrieved from: http://articles.cnn.com/2006-05-18/us/identity.theft_1_identitytheft-bank-employee-bankheist?_s=PM:US.

[18] Taylor, I (1999), The debatable dozen, Supply Management, 2 December, pp. 40-1.

[19] Verizon. (2016). 2016 Data Breach Investigations Report. Retrieved from http://www.verizonenterprise.com/verizon-insights-lab/dbir/2016/

[20] Wagner, B., Fillis, I. and Johannsson, U. (2002), E-commerce adoption and Esupply Strategy in the Scottish Smaller Firm, 11th IPSERA conference, Enschede, pp. 721-33.

[21] Wescott, D. (2010). CWSP Certified Wireless Security Professional Official Study Guide. Sybex Publishing.

[22] Young, S. (2004). Hacker's Handbook: The Strategy Behind Breaking Into and Defending Networks. Boca Raton, FL: Auerbach Publications. 